\title{
65. İletişim ve çeviri: Kitle iletişim kuramlarına çeviri açısından bir yaklaşım
}

\section{Serhan DİNDAR 1}

\begin{abstract}
APA: Dindar, S. (2021). İletişim ve çeviri: Kitle iletişim kuramlarına çeviri açısından bir yaklaşım. RumeliDE Dil ve Edebiyat Araşturmaları Dergisi, (23), 1012-1026. DOI: 10.29000/rumelide.949975.
\end{abstract}

\section{Öz}

İletişim ve çeviri kavramları birbiriyle yakın olarak ilişkilendirilebilir özelliklere sahiptirler. Tanımsal açıdan bakıldığında iletişim, bireylerin veya toplumların bir kanal aracılı̆̆ı ile aralarında bilgi ya da mesaj aktarımı yaparak birbirlerini anlamalarıdır. Özellikle de farklı dil dizgeleri arasında yapılan dillerarası çeviri ise, belirli bir dilde yazılmış orijinal metnin anlamının, içeriğinin ve vermek istediği mesajın çevirmen aracılığı ile erek dilde oluşan çeviri metinle hedef kitleye aktarılmasıdır. Bu durumda hem iletişimde hem de dillerarası çeviride bir kanal aracılı̆̆ı ile bireyler veya toplumlar arasında bir aktarım gerçekleşmektedir. Böylece, dillerarası çevirinin farklı toplumların birbirleriyle iletişim kurmalarını sağlayan bir aktivite olduğu söylenebilir. Farklı toplumlar arasında bir iletişim ağı kuran çevirinin aynı zamanda bir kitle iletişim aracı olduğu da belirtilebilir. İletişim ve dillerarası çeviri arasında sadece tanımsal olarak değil işleyiş veya süreç bakımından da yakın bir benzerlik bulunmaktadır. Söz konusu bu benzerlik, kitle iletişim kuramlarına çeviri bakış açısıyla yaklaşımı mümkün kılmaktadır. Bu çalışmanın amacı, kitle iletişim kuramlarından seçilen ve aynı zamanda iletişim alanının iki önemli kuramı olan Shannon-Weaver İletişim Kuramı ve Lasswell'in Genel İletişim Kuramı'na çeviri süreci bağlamında yaklaşarak kuramsal bir uyarlama yapıp ortaya çıkan iletişimsel çeviri sürecini ve iletişim-çeviri ilişkisini kuramsal açıdan vurgulamaktır. Benimsenen bu yaklaşımla, tümevarım yöntemi ile ilerleyecek olan çalışmanın sonucunda kitle iletişim kuramlarının çeviri sürecine uyarlanabildiği ve bu bağlamda kuramsal olarak da genel bir iletişimsel bir çeviri sürecinin oluştuğu sonucuna varılmıştır.

Anahtar kelimeler: İletişim ve çeviri, Shannon-Weaver İletişim Kuramı, Genel İletişim Kuramı, çevirmen, iletişimsel çeviri

\section{Communication and translation: An approach to mass communication theories from the perspective of translation}

\begin{abstract}
The concepts of communication and translation have characteristics which can be closely associated each other. In a definitional perspective, communication is understanding of individuals or societies each other by transferring information or message through a channel. Especially interlingual translation between different languages is transmission of the sense, content and intended message of the original text written in a specific language to the target audience with the translated text (in the target language) via the translator. In communication and interlingual translation, a transmission takes place through a channel to communicate individuals and societies with each other. So, it can be said that interlingual translation is an activity that enables different societies to
\end{abstract}

Dr. Öğr. Üyesi, Karamanoğlu Mehmetbey Üniversitesi, Yabancı Diller Yüksekokulu, Mütercim ve Tercümanlık Bölümü, Fransızca Mütercim ve Tercümanlık ABD (Karaman, Türkiye), serhandindar@kmu.edu.tr, ORCID ID: oooo-ooo17138-672X [Araştırma makalesi, Makale kayit tarihi: 14.04.2021-kabul tarihi: 20.06.2021; DOI: 10.29000/rumelide.949975]

RumeliDE Dil ve Edebiyat Araştırmaları Dergisi Osmanağa Mahallesi, Mürver Çiçeği Sokak, No:14/8 Kadıköy - İSTANBUL / TÜRKIYE 34714 e-posta: editor@rumelide.com tel: +90 $5057958124,+902167730616$
Address

RumeliDE Journal of Language and Literature Studies

Osmanağa Mahallesi, Mürver Çiçeği Sokak, No:14/8

Kadıköy - ISTANBUL / TURKEY 34714

e-mail: editor@rumelide.com,

phone: +90 505 7958124, +90 2167730616 


\begin{abstract}
communicate with each other. It can be stated that translation which establishes a communication network between societies is also a mass media. There is a close correspondence between communication and interlingual translation not only in definition but also in process. This correspondence makes it possible to approach mass communication theories from the perspective of translation. The objective of this study is to demonstrate theoretically the relation of communication-translation and the emergent communicative translation process and to make a theoretically adaptation by approaching within the context of translation process to ShannonWeaver Communication Theory and Lasswell's General Communication Theory which are chosen from communication theories and also two important theories of communication studies. As a result of the study which will proceed with the inductive method, it was concluded with this approach that mass communication theories can be adapted theoretically to the translation process and that a general communicative translation process is theoretically consisted.
\end{abstract}

Keywords: Communication and translation, Shannon-Weaver Communication Theory, General Communication Theory, translator, communicative translation

\title{
Giriş
}

İletişim ve çeviri, insan hayatında önemli yeri olan iki uygulamadır. Günlük hayatımızda sıkça deneyimlediğimiz bu iki kavram, insanlık için gelişimi, öğrenmeyi, bilgi aktarımını ve bir şeyleri anlayıp yorumlamayı sağlamaktadır. İletişim ve çeviri, kavramsal olarak kapsayıcı özellikte olup farklı şekillerde yapılarak gerçekleşebilmektedir. İletişim ve çevirinin geçmişine bakıldığında, her ikisinin de insanlığın var olmasıyla birlikte doğrudan ya da dolaylı bir şekilde ortaya çıkmış olduklarını söyleyebiliriz. Her ne kadar farklı gibi görünseler de ve kendi içlerinde birtakım özellikler gösterseler de iletişim ve çeviri yakından ilişkilendirilebilecek kavramlardır. Özellikle de iletişim ve dillerarası çevirinin süreçleri bakımından işleyişlerinin, amaçlarının ve işlevlerinin benzerlik gösterdiğini ve hatta bazı durumlarda aynı olduğunu belirtebiliriz. İletişim ve çeviri ilişkisi zaten var olan ve gerek çeviri bağlamında gerekse iletişim bağlamında kuramsal olarak da doğrudan ya da dolaylı bir şekilde dile getirilen bir durumdur. Özellikle de çevirinin bir iletişim kurma şekli olduğu, buna bağlı olarak da iletişimi sağlayan bir araç olduğu hem genel hem de kuramsal söylemler ile kabul edilmiş bir düşüncedir. Kuramsal bağlamda her ne kadar çeşitli söylemler dile getirilmiş olsa da bu iki kavram arasında tam anlamıla kuramsal uyarlamaya dayalı bir ilişkilendirme yapılmamıştır. Bu yüzden iletişim ve (dillerarası) çeviri ilişkisine kuramsal düzeyde daha açık bir ilişkilendirme yapma gereksinimi ortaya çıkmaktadır. İletişim-çeviri ilişkisi bağlamında, bazı kitle iletişım kuramlarına çeviri sürecini veya işleyişini yerleştirerek bir uyarlama yapmak mümkündür. Bu fikirden hareketle, çalışmamızda tümevarım yöntemi ile öncelikle iletişim ve çevirinin ne olduklarını kuramsal tanımlamalar ve söylemler ile destekleyerek ele alıp çeviribilim açısından nasıl ilişkilendirildiklerine değineceğiz. Daha sonra bu ilişkilendirmeyi detaylı bir şekilde kuramsal temele taşıyarak temel iki kitle iletişim kuramı olan Shannon-Weaver İletişim Kuramı ve Lasswell'in Genel İletişim Kuramına çeviri süreci bağlamında yaklaşıp bu kuramları dillerarası çeviri sürecine uyarlayacağız. Böylece, kitle iletişim kuramlarına çeviri bağlamında yaklaşarak iletişim ve çeviri süreçlerinin kuramsal olarak daha açık bir şekilde örtüşebildiğini ve bunun sonucunda da ortaya genel bir iletişimsel çeviri sürecinin çıktığını göstermeye çalışacağız.

\section{İletişim ve çeviri ilişkisi}

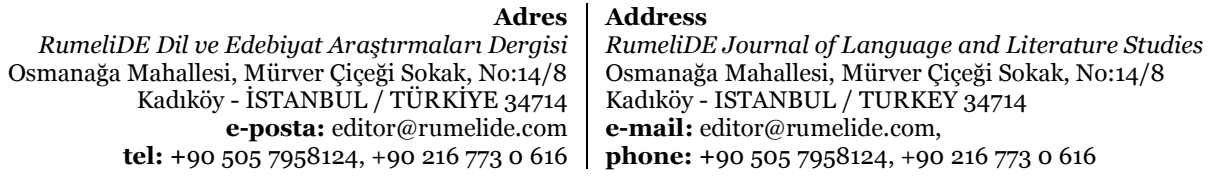

tel: +90 505 7958124, +90 2167730616 
Communication and translation: An approach to mass communication theories from the perspective of translation / S. Dindar (pp. 1012-1026)

İletişim ve çeviri ilişkisine geçmeden önce genel anlamda bu iki kavramın ne olduklarına ayrı ayrı değinmek faydalı olacaktır. Çeviriden daha eski bir deneyim olan iletişim, insanların var olmasıyla birlikte ortaya çıkan bir durumdur. Eski dönemlerde, insanlar fiziksel olarak konuşma yetisini geliştirmeden önce çıkarılan sesler aracılı̆̆ı ile iletişim kurmuşlardır. Daha sonra insanların dil yetisini geliştirmesi ve seslerin konuşulan dile dönüşmesiyle ortaya çıkan doğal dil, insanlar arasındaki iletişimi sağlayan bir araç olmuştur. Böylece insanlar, birbirleriyle anlaşarak, öğrenerek, bilgi aktararak ve gelişerek yaşamlarını sürdürmeye devam etmişlerdir. Bütün bu öğrenme, aktarma, anlaşma ve gelişme durumları da genel olarak iletişim ile koşut giden durumlardır. Basit anlamda iletişim, "bir gönderen birimden bir alıcı birime iletilerin aktarım işi” olarak tanımlanır (Bulduklu \& Karaçor, 2019, s. 9). İletişim süreci, bir göndericinin belirli bir mesajı veya iletiyi bir kanal aracılığı ile karşı taraf veya alıcıya iletmesi şeklinde işleyiş göstermektedir. Bireyin içinde bulunduğu durumu, hissettiği duyguyu, düşüncelerini veya bilgilerini karşı tarafa aktarmasının yanı sıra yaşamını sürdürdüğü dış dünyayı ve olup bitenleri anlaması, yorumlaması için de iletişim gereklidir (Bulduklu \& Karaçor, 2019, s. 9). Böylece birey, iletişim kurarak diğerleriyle ve dış dünya ile bir etkileşime girmektedir ve bu yolla da toplum içinde varlığını, gelişimini sürdürmektedir. İletişim kurmak insan için temel ve gerekli bir ihtiyaç olarak görülebilir. İletişim sadece bireysel düzeyde işleyiş gösteren bir süreç değildir. İnsan her ne kadar bireysel bir varlık olsa da içinde bulunduğu bir toplumun olduğu da yadsınamaz bir gerçektir. Bu bağlamda, her ne kadar bireysel olarak iletişim kurulsa da daha geniş ölçekli bakıldığında iletişim, toplumun bir parçası olan insandan çıkarak geneli kapsayıcı veya toplumsal bir yöne doğru ilerleyiş gösterebilmektedir. Çünkü toplumların veya toplulukların iletişim kurması çok sayıda bireyin iletişim kurması veya bir göndericinin birden fazla kişiye bir kanal aracılı̆̆ı ile ileti göndermesi şeklinde gerçekleşmektedir. Bu durumda, geniş kitlelere ulaşma durumu söz konusudur. "Kitleler denilince akla ilk gelen aynı anda çok sayıda kişiye erişmek, onların tutum ve davranışları üzerinde etkide bulunmaktır" (Bulduklu \& Karaçor, 2019, s. 10). Böylece, birden fazla kişi birbiriyle veya bir kişi daha geniş kitlelerle iletişim kurarak onlarla etkileşime girebilmektedir. Özellikle de bir kişinin ya da kişilerin geniş kitleler ile iletişim kurması tıpkı insanların bireysel olarak iletişim kurmasındaki gibi farklı şekillerde ve farklı kanallar aracılığı ile gerçekleşebilmektedir. Bireysel bağlamda, kişinin konuşarak (doğal dil sistemi ile) alıcıya ileti göndermesi mümkündür. Bunun yanı sıra, doğal dil dışında jest, mimik ve hareketler veya farklı gösterge dizgeleri (işaret dili, resim, müzik, heykel gibi görsel-işitsel araçlar) ile iletişim kurulabilmektedir. Kitlesel bağlamda ise, daha geniş kitlelere ileti göndermek ve erişmek durumu söz konusu olduğundan bir kitle iletişimi gerçekleşmektedir. Böylece, devreye kitle iletişim araçları girmektedir. "Medya olarak da adlandırılan kitle iletişim araçları, bilgi, düşünce ve görüşleri iletmek için kullanılan araçları ifade etmektedir" (Bulduklu \& Karaçor, 2019, s. 11). İletişim sürecinde mesajın doğru ve uygun şekilde alıcıya ulaşmasını, iletişimin gerçekleşmesini sağlayan aracı nesne kitle iletişim araçlarıdır. $\mathrm{Bu}$ araçlar çeşitlilik gösterebilmektedir. Kitap, radyo, televizyon, gazete, bilgisayar, telefon vb. yazıll, sözlü, görselişitsel birçok nesne kitle iletişim aracı niteliğindedir. Farklı dil ve toplumlara ait kitle iletişim araçlarının sağladığı aktarım bağlamında, kaynak metin mesajının çevirmen aracılığı ile erek kitleye aktarılması işi olan çeviri eylemi de bir kitle iletişim aracı olarak değerlendirilebilmektedir. Bu durumu detaylandırmadan önce genel olarak çevirinin ne olduğuna değinmek faydalı olacaktır.

Çeviri, özellikle de bir eylem olarak çok eskilere dayanan bir uygulamadır. İnsana özgü olan çeviri, farklı dillerin ortaya çıkışı ile birlikte bir gereksinim olarak doğmuştur. Bu çıkış, Babil Kulesi efsanesine dayanmaktadır. Kısaca bu efsaneye göre, insanlar Tanrı'ya ulaşmak için gökyüzüne uzanan bir kule inşa etmeye başlarlar. Bu durum karşısında öfkelenen Tanrı, kuleyi yıkar ve onları cezalandırmak için o zamana kadar aynı dili konuşan insanların konuştukları dili bölerek karıştırır. Bunun sonucunda ortaya farklı diller çıkar. Tanrı, ortaya çıkan farklı dilleri oradaki insanlara verir ve 
onların birbirleriyle anlaşmasına engel olur. Böylece dil birliği bozulur. Toplumdaki herkes farklı bir dil konuştuğu için anlaşma sağlanamaz ve iletişim kurulamaz. Bu yüzden de kuleyi yeniden inşa edemeyip dağılırlar. İşte bu iletişimsizleşme durumu da zamanla çeviri ihtiyacını doğurmuştur. Başka bir deyişle, çeviri eylemi bir iletişim yokluğu durumunda ortaya çıkmıştır ve burada amaç, bozulan ya da yok olan iletişimin yeniden sağlanmasıdır. Çevirinin ortaya çıkış sebebi ve amacı bile bizi onun bir iletişim aracı olduğu fikrine götürmektedir. Çünkü insanlar arasında iletişim kurmayı sağlayan bir araç olarak kabul edilen doğal dilin iletişim kurma durumu farklı diller söz konusu olduğunda da geçerliliğini ve gerekliliğini korumaktadır. Dilin (fr. langue) ve dil yetisinin (fr. langage) bir iletişim aracı olduğu dilbilim alanında çalışmalar yapan kuramcılar tarafından kuramsal söylemler ile farklı açılardan doğrudan ya da dolaylı bir şekilde doğrulanmıştır². Bu kuramcılar, dil ve dil yetisi üzerinden dilsel iletişim sürecini betimleyen iletişimsel modellemeler yapmışlardır. Çalışmanın sınırları gereği bu söylemlere tek tek değinmeyeceğiz fakat genel olarak bakıldığında dilbilim kuramcıları dilsel iletişimde de gönderici (fr. destinateur/ ing. sender), mesaj (fr. message/ ing. message), kod ya da dil (fr. code/ ing. code) ve alıcı (fr. destinataire/ ing. receiver) gibi sınıflandırmalar yaparak dilin insanlar arasındaki iletişimi sağlayan bir sistem olduğunu vurgulamışlardır. Çevirinin ortaya çıkış nedenine geri dönecek olursak, aynı dili konuşan insanların iletişim kurma zorunluluğundan farklı olarak aynı dil içinde değil de farklı diller arasında bir iletişim kurma zorunluluğu ortaya çıkmıştır. Bu yüzden, farklı dillerin ortaya çıkışından sonra dağılan ve gelişen bu dillere koşut olarak iletişim kurma ihtiyacı da artmaya başlamıştır. Farklı diller arasında iletişim kurma ihtiyacı da insanları dil öğrenmeye teşvik etmiştir. Kendi dili dışında farklı diller öğrenmeye başlayan insanlar (gerek yazılı gerekse sözlü) çeviri yoluyla bu diller arasında iletişim kurmaya başlamışlardır. Böylece dillerarası çeviri eylemi, yaygınlaşmaya ve gelişmeye devam etmiştir.

Farklı diller arasında yapılan çeviri türü, dilbilimci Roman Jakobson (1963) tarafından dillerarası çeviri (fr. traduction interlinguale / ing. interlingual translation) olarak adlandırılıp "dilsel göstergelerin başka bir dil aracılığı ile yorumlanması" şeklinde tanımlanmıştır33 (s. 79). Dili kendine has bir gösterge sistemi olarak gören Jakobson, dillerarası çeviri sürecini aynı gösterge türleri (dil) arasında fakat farklı dillerde yorumlanarak aktarılması şeklinde ele almıştır. Temel anlamda ve dilbilim bağlamında düşünülen bu görüş zamanla değişime uğrayarak yerini (dillerarası) çevirinin sadece dilsel bir aktarım olmadığı görüşüne bırakmıştır. Çünkü dillerarası çeviride amaç her ne kadar dilsel iletişimi kurmak olsa da farklı dillerin konuşulduğu farklı coğrafya ve toplumlarda kültürel değerlerin olduğu da yadsınamaz bir gerçektir. Her farklı dilin, içinde bulunduğu kendine has bir kültürü vardır. Böylece farklı diller arasında kültür farklılığı da ortaya çıkmaktadır. Bu bağlamda, dillerarası çeviri eylemiyle birlikte aslında sadece dillerarası değil, kültürlerarası (toplumlararası) bir aktarım da sağlanmaktadır. Dil, çeviri eylemi için bir araçtır, çevirmen dili çeviriyor gibi görünse de arka planda kültürel bir aktarım da yapmaktadır. Çünkü dillerarası çevirinin bir amacı da bir kültürü başka bir kültürde oluşturmaktır. Böylece dillerarası çeviri hem dilsel hem de kültürel bir iletişim aracı olma konumundadır. Buradan hareketle dillerarası çeviriyi basit anlamda, bir dilde ve kültürde yazılmış ya da söylenmiş olan metni, başka bir dil ve kültüre aktararak iletişim kurma eylemi olarak tanımlayabiliriz. Çeviri ile kurulan iletişim ağı, farklı toplumların birbirini tanımasını, dünya görüşünün oluşmasını ve gelişimini sağlamaktadır.

Genel olarak çeviri eyleminin yaygınlaşması ve gelişmesiyle birlikte çeviri ile ilgili kuramsal söylemler ortaya çıkmaya başlamıştır. Ortaya çıkan kuramsal söylemler de zamanla evrilerek çeviribilim adı

Bkz. F. de Saussure, R. Jakobson, K. Bühler, L. Bloomfield vd.

Çalışma boyunca yabancı kuramcılardan yapılan alıntıların Türkçeye çevirileri aksi belirtilmedikçe yazar tarafından yapılmıştır.

RumeliDE Dil ve Edebiyat Araştırmaları Dergisi Osmanağa Mahallesi, Mürver Ciçeği Sokak, No:14/8 Kadıköy - ISTANBUL / TÜRKIYE 34714 e-posta: editor@rumelide.com tel: +90 $5057958124,+902167730616$
Address

RumeliDE Journal of Language and Literature Studies

Osmană̆a Mahallesi, Mürver Çiçeği Sokak, No:14/8

Kadıköy - ISTANBUL / TURKEY 34714

e-mail: editor@rumelide.com,

phone: +90 $5057958124,+902167730616$ 
Communication and translation: An approach to mass communication theories from the perspective of translation / S. Dindar (pp. 1012-1026)

altında tartışılmaya başlanmıştır. Çeviriyi kuramsal olarak ele alıp inceleyen, araştıran, tartışan ve detaylandıran çeviribilim, çeviri eyleminin bilimi olarak gelişip kendine bir çalışma alanı edinmiştir. Çevirinin bir iletişim süreci olduğu görüşü, çeviribilim alanında da kabul gören bir düşünce ve tanımlamadır. Alanda çalışmalar yapan kuramcılar, iletişim-çeviri ilişkisine dair kuramsal tanımlamalarda bulunup çeviri kuramlarında çevirinin iletişimsel bir süreç olduğuna da değinmişlerdir. Öne çıkan bazı kuramcılar ve söylemlerine değinecek olursak, ilk olarak Peter Newmark'tan bahsedebiliriz. Çeviriye iletişimsel boyutta yaklaşan kuramcı Peter Newmark'tır. Newmark iletişimsel çeviriyi "kaynak metnin kültür odaklı ifadelerinin bağlamsal anlamını ve içeriğini hedef dil okuyucusunun kolayca kabul edebileceği şekilde aktarılması işlemi” olarak tanımlamaktadır (Yalçın, 2015, s. 113). Newmark, iletişimsel çeviriyi kaynak metnin içinde bulunan kültürel unsurların, söylemlerin veya deyişlerin uygun ve kabul edilebilir bir şekilde erek kültür bağlamında erek odaklı olarak aktarılması şeklinde değerlendirmektedir. Kuramcı, çevirinin iletişimsel boyutuna süreç odaklı bir şekilde değil de daha çok kaynak metnin anlamının, söylemek veya vermek istediği kültürel mesajların aynı etkiyle erek metinde sağlanması şeklinde yaklaşmaktadır. Böyle bir aktarım durumunda, kaynak kültür ve erek kültür arasında bir iletişim sağlanmış olur. Çünkü dillerarası çeviride amaç kaynak metnin anlamını, içeriğini ve söylemek istediğini, tıpkı iletişimde olduğu gibi, alıcıya ya da hedef kitleye aynı etkiyle ulaştırmaktır.

Dilbilim ve çeviribilim kuramcısı Jirí Levy ise, çevirinin sadece dilsel bir olgu olmadığını, çevirinin iletişim bağlamında ele alınması gerektiğini vurgulamıştır. Bir iletişim süreci olan çeviride amaç, kaynak metin bilgisini erek okuyucuya iletmektir (Rakovà, 2016, s. 139). Levy için çeviri ve iletişimdeki ortak amaç, mesajı (anlam) karşı tarafa aktarmaktır. Bu bakımdan Levy'nin, çeviri ve iletişim arasında bir benzetme yapmış olduğunu söyleyebiliriz. Öte yandan Levy, çeviri metnin bir yeniden üretim olmasının yanı sıra kendi başına da bağımsız bir metin özelliği gösterdiğini belirtmiştir (Tahir Gürçağlar, 2011, s. 119). Erek metin, her ne kadar kaynak metnin bir çeviri ürünü olsa da Levy için tek başına bağımsız bir metin özelliği de göstermektedir. Bu bağlamda Levy, toplumsal ve kültürel bir özellik gösteren çeviri metnin oluşum sürecini çevirmenin karar alma süreci olarak yorumlamıştır.

Bir diğer çeviri kuramcısı Katharina Reiss (2000), dillerarası çeviriyi "kaynak dil metninin işlevsel olarak eşdeğeri olabilecek bir erek dil metninin üretilmesini amaçlayan ve iletişim süreciyle sağlanan bir ikidilli durum" olarak tanımlamaktadır (s.160). Reiss için bu süreç, kaynak ve erek dillerden oluşan araçlar (İng. media), kanal ya da aracı (İng. medium), aynı zamanda ikincil gönderen (İng. secondary sender) olan çevirmenden oluşmaktadır. Bu durumda da çeviri işlemi ikincil bir iletişime işaret etmektedir (Reiss, 2000, s. 160). Çünkü, kaynak metin yazarı ile kaynak okuyucu arasında o dilde oluşmuş metin aracılığı ile birincil bir iletişim süreci oluşmaktadır. Kaynak dil ve kültürü bilen ya da o kaynak kültürden olan çevirmen de kaynak metnin alıcısı (okuyucusu) konumunda kaynak metin iletisini alarak onu erek dil ve kültüre aktarır. Böylece ikincil gönderici konumuna geçen çevirmen, kaynak metin ve erek kültür (kitle) arasında ikincil bir iletişim süreci meydana getirir. Bu süreçte, kaynak ve erek diller de araç konumundadırlar. Kaynak dil, yazar ve okuyucu kitle ya da bu kitlenin bir parçası olan çevirmen için, erek dil ise çevirmen ve erek okuyucu için bir çeşit iletişim aracıdır. Hem kaynak metin için hem de erek metin için mesaj aktarımında araç görevi gören doğal diller çevirmen kanalı ile birbirine aktarılır. Reiss'ın yaklaşımı bağlamında dillerarası çeviriyi iletişimin iletişımi olarak düşünebiliriz. Bu bağlamda çeviriyi iki aşamalı bir iletişim süreci olarak ele alan Reiss'ta çevirinin hem bir iletişim aracı olduğunu hem de ikincil düzeyde bir iletişim sağladığını söyleyebiliriz.

Çeviriye işlevsel bir bağlamda yaklaşan Christiane Nord ise, "çevirinin bir iletişim olgusu olduğunu kabul eder" (Yazıcı, 2005, s. 156). İletişimde söz konusu olan gönderici, alıcı, ileti gibi durumlar çeviri

RumeliDE Dil ve Edebiyat Araşttrmaları Dergisi Osmanağa Mahallesi, Mürver Çiçeği Sokak, No:14/8 Kadıköy - ÍSTANBUL / TÜRKIYE 34714 e-posta: editor@rumelide.com tel: +90 $5057958124,+902167730616$
Address

RumeliDE Journal of Language and Literature Studies

Osmanağa Mahallesi, Mürver Çiçeği Sokak, No:14/8

Kadıköy - ISTANBUL / TURKEY 34714

e-mail: editor@rumelide.com,

phone: +90 $5057958124,+902167730616$ 
için de geçerlidir. Amaç, göndericinin iletiyi alıcıya en iyi şekilde iletebilmesidir (Yazıcı, 2005, s. 157). Nord, tıpkı Newmark gibi, dillerarası çeviri bağlamında kaynak iletinin kendi kültüründeki işlevini erek metin ve kültür üzerinde sağlayıp sağlayamadığı konusuna yoğunlaşmaktadır. Ayrıca çeviri sürecini gönderici, ileti ve alıcı bağlamında bir iletişim sürecine benzeterek onun bir iletişim kurma şekli olduğu fikrini desteklemektedir.

İşlevsel yaklaşımı benimseyen ve çeviriyi bir iletişim süreci olarak tanımlayan diğer bir kuramcı da Justa Holz-Mänttäri'dir. Çeviriyi belirli durumlar ve bağlamlara uygun metinler üretmeyi amaçlayan bir kültürlerarası iletişim süreci olarak tanımlayan kuramcı, bu bağlamda yararcı bir yaklaşım sergilemektedir (Rakovà, 2016, s. 146). Kültürler arasındaki iletişimi sağlayan dillerarası çeviride amaç, etkili bir iletişim kurarak kaynak metindeki kültürel unsurları erek metne aktarmaktır. Bu yüzden de kaynak metnin yapısı ve işlevi önemlidir. Çevirmen de kültürel unsurları iletişimsel amaca uygun bir şekilde aktarır (Rakovà, 2016, s. 147). Kuramcı için, kaynak metnin türü ve işlevi hatta kurduğu iletişim çeviri açısından da önemlidir ve bu gibi durumlar erek metinde de sağlanmalıdır. Böylece Mänttäri’nin de Newmark ve Nord'da olduğu gibi, çeviride kültürel unsurların aktarımı bağlamında kültürel iletişime ayrıca metin türü ve işlevine önem verdiğini söyleyebiliriz.

İletişim ve çeviri ilişkisine değinen önemli bir diğer çeviribilimci Antoine Berman'dır. Aynı zamanda çevirmen de olan kuramcı, dillerarası çeviriyi kaynak dilden varış diline mesaj aktarımı sağlayan bir iletişim süreci olarak değerlendirmektedir (Berman, 1999, s. 70). Çeviri durumunda da iletişimde olduğu gibi belirli bir dilde bir gönderici tarafından gönderilen mesaj başka bir dilde bir alıcı için kodlanarak oluşturulmaktadır (Berman, 1999, s. 70). Çeviri süreci bir iletişim kurma sürecidir. Çeviri, erek okuyucu ve kaynak metin arasında iletişim ağı kurmaktadır. Berman, bu bakış açısını daha çok bilgi aktarımı sağlayan teknik metin çevirisi için desteklemektedir. Yazınsal metin çevirisinde durum biraz daha farklıdır. Çünkü ona göre, yazınsal metinler salt bilgi aktarımı yapmazlar. Bu tip metinlerin çevirisinde metnin iç dünyası, gizemli yanları ve kavranması gereken anlamın (fr. sens) aktarılması gerekmektedir. Yazınsal metinler bilgi aktarsalar bile aynı zamanda okuyucuya bir dünya ve deneyim sunarlar (Berman, 1999, s. 76). Amaç sadece anlaşılmayan olanı anlaşılır kılıp anlamayan ile anlaşılmayan arasında iletişim kurmak değildir. Amaç, yabancı olanı kendi dil uzamında açmak, açığa çıkarmak veya meydana getirmektir. Dillerarası çevirinin doğasında olan şey budur ve çeviri etiği de bunu gerektirmektedir. Çeviri, yabancıyı kendi dilinde yabancı olarak açığa çıkarma arzusunun ortaya çıkmasıdır fakat her durumda çevirinin temel amacı kültürel bir iletişim kurmaktır (Berman, 1999, s. 76). Böylece gerek teknik metinlerin gerekse yazınsal metinlerin çevirisinde farklı dil, toplum ve kültürler arasında iletişim kurulmuş olunur. Berman, iletişim ve çeviri ilişkisine felsefi bir bakış açısıyla yaklaşmaktadır. Kuramcı, çevirmenlik deneyimlerinden de yola çıarak yazınsal metin çevirisinin her ne kadar iletişimle sınırlı kalmayan ve onu aşan bir boyutu olsa da bilgi aktarımı sağlayabileceği ve kültürel bir iletişim kurabileceği düşüncesindedir. Bu bağlamda, çevirmenkuramcının genel anlamda dillerarası çeviriyi kültürel (kültürlerarası) bir iletişim aracı olarak değerlendirdiğini belirtebiliriz.

Çeviribilim alanında önemli çalışmalar yapan iki kuramcı Basil Hatim ve Ian Mason çeviri sürecini iletişim bağlamında tanımlamaktadırlar. Onlara göre "çeviri, sosyal bir bağlamda gerçekleşen iletişim sürecidir" (Hatim \& Mason, 1990, s. 20). Hatim ve Mason, bir iletişim süreci olarak çevirinin sosyal tarafını ele almaktadırlar. Çünkü iletişim gibi çeviri de insana özgü bir uygulamadır ve insan işin içine girdiğinde sosyal veya toplumsal durumlar da göz önüne alınmalıdır. Öte yandan Hatim ve Mason "çeviriyi iletişimsel bir söylem, çevrilecek metni (kaynak metin) ise iletişimsel bir uzlaşım olarak ele almaktadırlar" (Guidère, 2010, s. 61). Çevirmen ise, dinamik iletişimi sağlayan bir iletişimcidir

Adres Address

RumeliDE Dil ve Edebiyat Araştırmalar Dergisi $\quad$ RumeliDE Journal of Language and Literature Studies Osmanağa Mahallesi, Mürver Çiçeği Sokak, No:14/8 Osmanağa Mahallesi, Mürver Çiçeği Sokak, No:14/8 Kadıköy - İSTANBUL / TÜRKIYE 34714 Kadıköy - ISTANBUL / TURKEY 34714 e-posta: editor@rumelide.com e-mail: editor@rumelide.com, tel: +90 505 7958124, +90 2167730616 phone: +90 505 7958124, +90 2167730616 
Communication and translation: An approach to mass communication theories from the perspective of translation / S. Dindar (pp. 1012-1026)

(Munday, 2016, s. 160). Böylece çeviri eylemi bir iletişimsel eylem olma niteliği göstermektedir. İletişimsel süreçte ise olup biten olay (alan), iletişimsel sürecin katılımcıları (eyleyenler) ve iletiyi aktarmak için seçilen aracı analiz etmek gerekmektedir (Hatim \& Mason, 1990, s. 55). Bu açılardan çeviri sürecinin sosyal bir çözümlemesi yapılması gerektiğini vurgulayan Hatim ve Mason, çeviriyi eyleyenlerin, konunun ve aracı bir kanalın olduğu iletişimsel bir eylem olarak görmektedirler. Böylece iletişim süreci olarak çeviriyi sosyo-kültürel bir bağlamda ele alıp incelemiş olduklarını söyleyebiliriz.

Çeviri sürecinde değinilmesi gereken bir başka konu da çevirmendir. Çeviri sürecini yöneten ve gerçekleştiren özne olan çevirmen, bir birey olarak içinde yaşadığı toplumda şekillenen sosyal bir öznedir. Çevirmenin çeviri sürecine etkisi yadsınamaz. Bu bağlamda, çeviri sürecini başlatan ve bitiren çevirmenin iki dil ve toplum arasında iletişim kuran aracı özne olduğunu söyleyebiliriz. Çeviren özne iki farklı dili konuşan kültür arasında iletişim uzmanı veya elçisi olarak bulunmaktadır (Munday, 2016, s. 187). Her iki dili (kaynak dil- erek dil) bilen ve her iki kültürü tanıyan (kaynak kültür- erek kültür) özne olarak çevirmen, iletişim süreci olarak çeviride bir çeşit iletişim kanalı olma görevini üstlenmektedir.

Çeviri ve iletişim ilişkisi ile ilgili değinmiş olduğumuz çeviribilimsel söylemlere baktığımızda, ortak görüşün çeviri sürecinin bir iletişim süreci olduğunu söyleyebiliriz. Çeviribilim alanında bu konu hakkında yapılan başka söylemler de elbette bulunmaktadır. Bahsetmiş olduğumuz öne çlkan kuramsal söylemler, çeviri ve iletişim ilişkisi konusuna farklı açılardan yaklaşmaktadırlar. Bazıları bir iletişim süreci olarak çeviriye sosyo-kültürel açıdan yaklaşıp tanımlarken, bazıları da çevirmene veya kaynak-erek metinlere yoğunlaşarak ya da dilsel veya erek odaklı açıdan yaklaşarak ele almışlardır. Ayrıca, bu sürece bağımsız bir erek metin bağlamında yaklaşan veya konuya daha felsefi bir açıdan yaklaşan kuramcılar da bulunmaktadır. Öte yandan, çeviri ve iletişim süreci açısından benzerlik kurarak gönderici, araç, aracı açılarından ilişkilendirmeler de yapılmıştır. Genel anlamda baktığımızda, daha önce de belirttiğimiz gibi çeviri alanındaki kuramsal söylemler çeviri ve iletişim ilişkisini farklı açılardan ele alıp incelemiş ve çeşitli noktalara varmışlardır. Biz de çeviribilim alanındaki bu tarz yaklaşımları irdelemek ve detaylandırmak için farklı olarak iletişim kuramlarına çeviri açısından yaklaşıp seçmiş olduğumuz Shannon-Weaver İletişim Kuramı ve Genel İletişim Kuramı'nı çeviri süreci işleyişine uyarlayacağız. Bu kuramları tercih etme nedenlerimiz, her iki kuramın da iletişim alanında temel özellik göstermesi, iletişim sürecini genel anlamda betimlemesi ve bu bağlamda da kuramların çeviri süreci perspektifinden bir yaklaşıma uygun olmasıdır.

\section{Shannon-Weaver kuramı ve çeviri}

İletişim çalışmalarında Shannon-Weaver Modeli (İng. Shannon-Weaver Model), ve Matematiksel İletişim Modeli (İng. Mathematical Theory of Communication) adlarıyla da bilinen bu kuram, genel iletişim sürecini betimleyerek bir modelleme oluşturduğu için model olarak da ele alınmaktadır. Fakat, süreci betimlerken bir sınıflandırma yaparak tanımlamalar oluşturması ve döneminde farklı bir yaklaşımı benimsemesi açısından kuramsal özellik göstermektedir. 1949 yılında Amerikalı matematikçiler Claude Elwood Shannon ve Warren Weaver tarafından ortaya atılan bu kuram, ilk etapta kişilerarası iletişim sürecini betimlemiş olsa da zamanla kitlesel iletişim sürecini de kapsamaya başlamıştır. İletişimi doğrusal olarak ele alan Shannon-Weaver İletişim Kuramı, "bilgiyi veren bir kaynak tarafından gönderilen iletinin hedefe aktarımını çizgisel olarak ele almaktadır" (Bulduklu \& Karaçor, 2019, s. 66).

\footnotetext{
\begin{tabular}{r|l} 
Adres & Address \\
RumeliDE Dil ve Edebiyat Araşttrmalar Dergisi & RumeliDE Journal of Language and Literature Studies
\end{tabular}

Osmanağa Mahallesi, Mürver Çiçeği Sokak, No:14/8 Osmanağa Mahallesi, Mürver Çiçeği Sokak, No:14/8

Kadıköy - İSTANBUL / TÜRKIYE 34714 Kadıköy - ISTANBUL / TURKEY 34714

e-posta: editor@rumelide.com e-mail: editor@rumelide.com,

tel: +90 505 7958124, +90 2167730616 phone: +90 505 7958124, +90 2167730616
} 


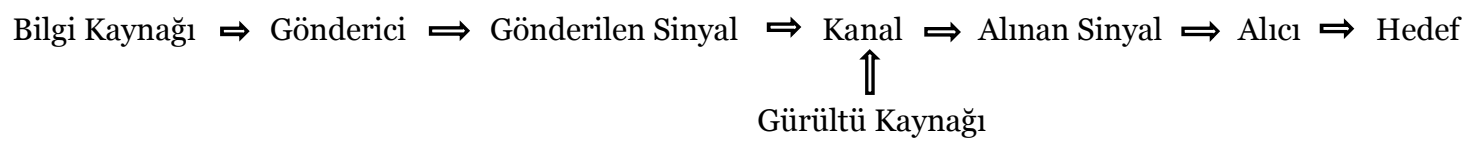

Şekil 1: Shannon-Weaver Modeli (Bulduklu \& Karaçor, 2019, s. 68).

Şekilde de görüldüğü gibi, bir bilgi kaynağından (İng. information source) çlkan ileti (İng. message) bir aktarıcı veya göndericide (İng. transmitter/ encoder) sinyale (İng. signal) dönüşür. Gönderilen sinyal bir kanal (İng. channel) aracılığı ile alıcı sinyal (İng. received signal) haline gelir. Daha sonra bu sinyal, alıcı (İng. receiver/ decoder) birime geçer ve hedefe (İng. destination) aktarılır. Buradaki bilgi kaynă̆ı iletinin çıtığı kaynaktır. Bilgi kaynağı bir kişi veya yayın olabilir. Kaynaktan çıkan bilgi ya da mesaj bir göndericiye geçer. Gönderici yani iletişim aracı, sinyali bir kanala ya da iletişimi sağlayan araca iletir. $\mathrm{Bu}$ kanal ile alıcı için sinyale dönüşen ileti alıcıya ya da alıcı araca (iletişim aracı) ulaşır ve alıcı üzerinden de hedefe varır. Bu kuramı diğerlerinden ayıran temel özellik, kitle iletişim araçlarını süreçte daha görünür kılması ve gürültü kaynağı (İng. noise source) unsuruna da yer vermiş olmasıdır. İletişim sürecinde bilgi kaynağından çıkan iletinin hedefe ulaşımı istenmeyen olumsuz faktörler tarafından engellenebilmektedir (Bulduklu \& Karaçor, 2019, s. 68). Bu faktörler gürültü, sinyal kopukluğu veya kesilmeler şeklinde olabilmektedir. Gürültü faktörü de iletinin hedefe doğru, anlaşlır ve uygun bir şekilde aktarılmasına engel olabilmektedir. Öte yandan bu kuram, iletinin varışını alıcı ve hedef olmak üzere iki aşamalı bir şekilde açıklamaktadır (Bulduklu \& Karaçor, 2019, s. 68). Başka bir deyişle, iletinin hedefe varmadan önce bir alıcıda şekillenmesi veya onu hedefe ulaştıracak bir nesnenin olması gerekmektedir. Bu nesne ya da alıcı bir iletişim aracı olmaktadır. Böylece, iletinin hedefe varmasıyla iletişim sağlanmış olur. İletişimin devam etmesi durumunda, hedef olan kişi ya da kitle, tepkisi veya verdiği karşılık ile yeni bir ileti oluşturursa hedef, bilgi kaynă̆g durumuna geçerek ilk bilgi kaynağına doğru iletişim sürecini yeniden başlatıp karşılıklı bir şekilde devam ettirebilir ya da başka yeni hedeflere doğru ilerletebilir.

Shannon ve Weaver'in, telefon laboratuvarında mühendis olarak telefon kabloları ve radyo dalgaları gibi iletişim kanalları üzerine yaptıkları çalışmalar sonucunda oluşturdukları bu kuram, iletişim sürecini matematiksel bir şekilde formüle eden kuramsal bir model olma özelliği göstermektedir. Shannon ve Weaver, iletişimi bir sinyal (ileti) aktarma süreci şeklinde ele alıp bu sinyalin hedefe sağlıklı bir şekilde aktarılıp aktarılmadığı konusu ile ilgilenmişlerdir (Bulduklu \& Karaçor, 2019, s. 67). Böylece iletişim sürecine betimleyici bir şekilde yaklaşmış olduklarını söyleyebiliriz. Her ne kadar fen bilimleri alanında çalışmalar yapan iki kuramcı tarafından ortaya atılmış olsa da Shannon-Weaver İletişim Kuramı, iletişim bilimi ve benzer (sosyoloji, antropoloji, psikoloji) sosyal bilimler alanındaki çalışmalara da hizmet etmektedir. İletişim sürecini çizgisel olarak tek yönlü konumlandıran ve hedefe doğru ilerleten bu kuram gerek kişiler arasında gerekse kitleler arasında (geniş kitleler arasındaki iletişim ya da tek bir göndericinin birden fazla alıcıya ileti aktarması) kitle iletişim araçları (telefon, televizyon, radyo vb.) ile kurulan iletişimde geçerli olabilmektedir. Bu yüzden Shannon-Weaver İletişim Kuramı, iletişim alanında yapılan kuramsal çalışmalarda önemli bir yer tutmaktadır.

Kişiler arasında veya daha geniş kitleler arasında iletişim kuran (dillerarası) çeviri de bir çeşit kitle iletişim aracı olarak iletişim sürecinde yer alabilmektedir. Bir kitle iletişim aracı olarak görülebilen çevirinin de kendi içinde bir iletişimsel işleyişi veya süreci bulunmaktadır. Bir dilde yazılmış metnin söylediği şeyleri başka bir dile aktaran çeviride de iletişimde olduğu gibi bir mesajı hedefe ulaştırma durumu söz konusudur. Bu benzerlik bağlamında, çeviri süreci işleyişini Shannon-Weaver İletişim Kuramı'ndaki iletişim sürecine yerleştirerek şu şekilde bir uyarlama yapmak mümkündür:

\begin{tabular}{r|l} 
Adres & Address \\
RumeliDE Dil ve Edebiyat Araşttrmaları Dergisi & RumeliDE Journal of Language and Literature Studies \\
Osmanağa Mahallesi, Mürver Çiçeği Sokak, No:14/8 & Osmanağa Mahallesi, Mürver Çiçeği Sokak, No:14/8 \\
Kadıköy - ISTANBUL / TÜRKIYE 34714 & Kadıköy - ISTANBUL / TURKEY 34714 \\
e-posta: editor@rumelide.com & e-mail: editor@rumelide.com, \\
phone: +90 505 7958124, +90 2167730616
\end{tabular}


Communication and translation: An approach to mass communication theories from the perspective of translation / S. Dindar (pp. 1012-1026)

$$
\begin{aligned}
& \text { Kaynak Metin Yazarı } \Rightarrow \text { Kaynak Metin } \Rightarrow \text { Kaynak Metnin Anlamı } \Rightarrow \text { Çevirmen } \Rightarrow \text { Kaynak Metnin Anlamı } \Rightarrow \\
& \Rightarrow \text { Erek Metin } \Rightarrow \text { Erek Kitle }
\end{aligned}
$$

Dillerarası çeviri sürecinde, yazılı çeviri bağlamında düşünecek olursak, öncelikle tek yönlü bir iletişim sürecinin olduğunu belirtebiliriz. Bu durumda ortaya, belirli bir dilde yazılmış olan bir orijinal kaynak metnin çıkması gerekmektedir. Oluşan kaynak metnin yazarı bilgi kaynağı durumundadır. Çünkü yazar, kendi bilgileri ya da anlatmak istedikleri doğrultusunda metnini oluşturmaktadır. Oluşan kaynak metin hem kendi kültüründe hem de çeviri süreci için gönderici konumundadır ve yazarın anlatmak istediklerini, metnin anlamını içermektedir. İçerdiği bu anlam ve anlatılmak istenen şey (ya da bunların kendi kültüründeki etkisi) gönderilen sinyal ya da iletidir. Kaynak metni çevirmeye karar veren çevirmen de her şeyden önce bir kaynak kültür okuyucusu olarak metni çeviri amaçlı okur ve metnin anlamını, söylemek istediklerini ve duygusal etkisini (gönderilen sinyal) özümser. Bu noktadan itibaren çevirmen bir kanaldır. Çünkü daha önce de belirttiğimiz gibi, çeviri sürecinin asıl öznesi olan ve çeviri eylemini gerçekleştiren kişi olarak çevirmen, kaynak ve erek dili bilen, her iki kültürü tanıyan biri olarak iki dil ve kültür arasında aracı yani kanal olma görevini üstlenmektedir. Çevirmen olmazsa ya da çeviri eylemini gerçekleştirmezse kanal da olmaz ve söz konusu iletişim gerçekleşemez. Kaynak metni başka bir dile ve kültüre geçiren çevirmen (kanal), alınan sinyal olan kaynak metnin anlamını, içeriğini ve etkisini öncelikle erek metni oluşturarak ona aktarır. Bu noktada erek metin, bir tür alıcı iletişim aracına dönüşür. Kaynak metin farklı bir dile aktarıldığı için biçimsel olarak değişse de (ki bu normal ve gerekli bir durum) içerik (anlam, mesaj, etki) olarak değişmemelidir. Biçimsel değişim dillerarası çevirinin doğasında vardır fakat çevirinin, var olan bir kaynak metinden hareketle yapıldığını unutmamak gerekir ve eğer çeviri sürecinde kaynak metin anlamsal olarak da değişirse ortaya erek metin değil yeni bir üretim çıkar ve çeviri işlemi gerçekleşmemiş olur. Kaynak metnin anlamı (iletisi ve sinyali) hedefe ulaşmadan önce bir araç-nesne olan alıcı erek metinde aynı içerikle farklı dilsel bir biçimde (erek dil biçimi ile) aktarılır. Oluşan erek metin (alıcı) ise hedef okuyucusuna ulaşmak üzere hazırdır ve erek kitleye (hedef) ulaşarak kaynak metnin anlamını ve etkisini o kitle üzerinde sağlayarak aktarır.

Shannon-Weaver İletişim Kuramı'nda bulunan gürültü kaynă̆ı yazılı çeviriden çok sözlü çeviri sürecinde devreye girebilmektedir. Ardıl ve andaş çeviride ardı ardına veya aynı anda dillerarası bir konuşma aktarımı yapıldı̆̆ı için çevresel gürültü faktörünün olması ve ileti aktarımında engel oluşturması ihtimali daha yüksektir. Fakat yazılı çeviride bu anlamda bir gürültü mümkün olmamaktadır. Bu süreç sözlü çeviri bağlamında farklı bir çalışma ile ele alınabilir. O yüzden buradaki (yazılı) çeviri sürecini Shannon-Weaver İletişim Kuramı'na uyarlarken gürültü kaynağı sürece dâhil edilmemiştir. Shannon-Weaver İletişim Modeli’ndeki dillerarası çeviri sürecinde, çeviri eyleminin amacı ve çevirmenin görevi kaynak metnin anlamını, söylemek istediği şeyi (mesajı) ve etkisini erek metin ile erek kitle üzerinde (aynı ya da yakın şekilde) sağlayabilmektir. Böylece, bu iletişim kuramı ve çeviride ortak amacın iletinin hedefe doğru, uygun ve bozulmadan aktarılabilmesi olduğunu söyleyebiliriz. Süreç olarak bakılırsa, Shannon-Weaver İletişim Kuramı'na yerleştirilebilen dillerarası (yazılı) çeviri süreci, bu bağlamda iletişimsel bir çeviri süreci olarak düşünülebilir. Söz konusu iletişimsel çeviri sürecinin de kaynak iletinin hedef kitleye düzgün bir şekilde ulaşmasıyla tamamlandığını söyleyebiliriz.

Çeviri sürecini yöneten kişi olarak çeviren özne daha önce de belirttiğimiz gibi iki dil ve kültür arasında bir iletişim elçisi olarak sürecin merkezinde olma konumundadır. Bu da çevirmen üzerinden çeviri

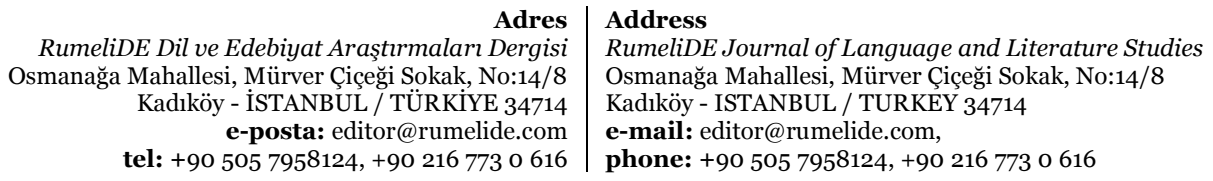


sürecini başka bir önemli iletişim kuramı olan Genel İletişim Kuramı’na yaklaştırmayı mümkün kılmaktadır.

\section{Genel iletişim kuramı ve çeviri}

İletişim biliminde $5 \mathrm{~W}$ İletişim Modeli (İng. Five $\mathrm{W}$ of Communication Model) ve Lasswell'in Genel İletişim Modeli (İng. Lasswell's General Communication Model) olarak da adlandırılan Genel İletişim Kuramı (İng. General Communication Theory), Amerikalı iletişim kuramcısı ve siyaset bilimcisi Harold Lasswell tarafından ortaya atılmıştır. Temeli her ne kadar daha eskiye dayansa da kuram 1948 yılında duyurulmuştur. Siyaset bilimi bağlamında ortaya çıkan bu kuram daha sonra kitle iletişim alanına uyarlanmıştır ve kendisinden sonra gelen birçok iletişim kuramına da temel olmuştur. Lasswell, Genel İletişim Kuramı'nda süreci betimleyen bir modelleme yaparak iletişim sürecine farklı bir açıdan yaklaşmıştır ve kendi döneminde düşünüldüğünde bu yaklaşım yenilikçi ve temel bir özellik göstermektedir. Bu bakımdan model, kuramsal bir nitelik kazanmaktadır. Genel İletişim Kuramı, o dönemdeki diğer kuramlar gibi iletişim sürecini doğrusal bir şekilde ele almaktadır. İletişim süreci birbirini tamamlayan ögelerin zincirleme bir şekilde ilerlemesiyle işleyiş göstermektedir. Lasswell her ne kadar beş sorudan oluşan bu modeli bir grafik şeklinde sunmasa da iletişim alanında yapılan kuramsal çalışmalarda araştırmacılar Lasswell'in genel iletişim sürecini şematize etmişlerdir (Bulduklu\& Karaçor, 2019, s. 72).

$$
\text { Kim? } \Longrightarrow \text { Neyi? } \Longrightarrow \text { Hangi Kanaldan? } \Longrightarrow \text { Kime? } \Longrightarrow \text { Hangi Etkiyle? }
$$

Şekil 2: Lasswell’in Genel İletişim Modeli (Bulduklu \& Karaçor, 2019, s. 71).

Lasswell’in Genel İletişim Kuramı, iletişim sürecini beş soru ile aşamalandırıp çözümlemektedir. Her bir soruyu bir iletişim ögesi cevaplamaktadır. "Kim?" sorusu kaynağa, "neyi?” sorusu iletilmek istenen mesaja, "hangi kanaldan?" sorusu, kanal veya iletim aracina, "kime?" sorusu, hedefe ve "hangi etkiyle?” sorusu da iletişimde amaçlanan etkiye karşllı gelmektedir (Yaylagül, 2008, s. 48). Bu soruların sıralaması küçük farklılıklarla yer değiştirebilse de temel sıralamanın bu şekilde olduğu söylenebilir. İlk soru olan "kim?" (İng. who?) sorusu (kim söylüyor?), iletişimi gerçekleştiren özneyi tanımlamak için sorulan bir sorudur. Genel İletişim Modeli’nin ilk sorusunun özneye yönelik olması iletişim sürecini başlatan kişi üzerinden bu sürecin çözümlenip betimleniyor olduğunun bir göstergesidir. “Kim?” sorusu, süreci başlatanın kim olduğunu ortaya çıkarır ve onu betimler. Bu aşama önemlidir çünkü iletişimin başlaması için gönderici bir öznenin olması gerekmektedir. Bu noktada, süreci başlatan göndericinin (kaynağın) ya da iletişimcinin varlığı ve kim olduğu hatta kişisel özellikleri de söz konusudur. "Neyi?” ya da "ne?” (İng. what?) sorusu (neyi söylüyor?), gönderici tarafından gönderilen mesaja yönelik bir sorudur. İletişimdeki temel amacın iletiyi hedefe ulaştırmak olduğu düşünülürse bir mesajın var olması ve söylenen şeyin ne olduğu bu bağlamda ön plana çlkmaktadır. Bu soru aslında içerik ile ilgilidir (Bulduklu\& Karaçor, 2019, s. 71). "Hangi kanaldan?" (İng. with which channel?) sorusu (hangi kanaldan söylüyor?), kanalın ne olduğunu bulmaya yönelik bir sorudur. İletinin hedefe ulaşmasını sağlayan ve bu ulaşım için gerekli olan araçlar (iletişim araçları) ya da aracılar birer kanal niteliğindedir. Böylece kanal, ileti gönderimini başlatan özneye (gönderici) yardım eden ve mesajının ulaşmasını sağlayan araçtır. "Kime?” (İng. to whom?) sorusu (kime söylüyor?) ise hedefi tanımlamak ve betimlemek için sorulur. Alıcı olan hedef, gönderilen mesajın varış noktasıdır. Alıcının ya da alıcı kitlenin kim olduğu ve özellikleri de iletinin ulaşmasında önemli rol oynamaktadır. Çünkü iletinin alıcıya ulaşmasıyla birlikte iletişim süreci tamamlanıp amacını gerçekleştirmiş olur. Son olarak "hangi etkiyle?” (İng. with what effect?) sorusu (hangi etkiyle

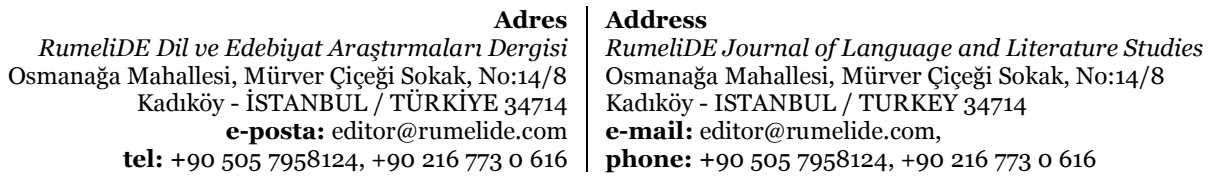


Communication and translation: An approach to mass communication theories from the perspective of translation / S. Dindar (pp. 1012-1026)

söylüyor?), hedef üzerindeki etkiye yönelik bir sorudur. Gönderilen iletinin amaç edindiği etkiyi, başka bir deyişle hedef kitle üzerinde bıraktığı etkiyi ve kanalın etkisini betimlemeye yönelik bu soru da süreçte önemli bir yer tutmaktadır. Çünkü amaçlanan etki alıcı kitle üzerinde sağlanmalıdır. Aynı sorular iletiyi alan hedefin iletişime devam etmesi durumunda ya da başka alıcılarla iletişim kurması durumunda da sorulabilmektedir.

Görüldüğü gibi Lasswell için iletişim süreci, bir gönderici kaynağın iletişim kanalı aracılı̆̆ıyla hedef kitle üzerinde bir etki yaratmak için ona ileti göndermesidir. Böylece, iletinin alıcıya düzgün bir şekilde ulaşması ve etkisini alıcı üzerinde sağlayabilmesi amaçlanır. İleti etkisinin sağlanıp sağlanamadığı da hedefteki alıcının tepkileri ile anlaşılabilmektedir. Bütün bu süreç sonunda iletişim sağlıklı bir şekilde gerçekleşmiş olur. Sorduğu sorularla iletişim sürecini betimleyen Lasswell, bu süreçte göndericinin kim olduğu, kanalın ne olduğu, iletinin alıcı üzerindeki etkisi, alıcının tepkileri ve tüm bu ögelerin özelliklerini betimlemeye yönelik olması bakımından iletişim sürecine sosyolojik bir bağlamda yaklaşmıştır. Bu sorgulama sonucunda da temel süreci farklı bir bakış açısıyla sınıflandırmış ve betimlemiştir. Böylece, Genel İletişim Kuramı'nın, iletişim sürecini sistematik ve betimleyici bir yaklaşımla ele alarak somutlaşmasına katkı sağladığını söyleyebiliriz.

Çeviri süreci açısından bakarsak, Lasswell'in iletişim sürecine ilişkin sorularını dillerarası çeviri süreci için de sormak mümkündür. Dillerarası çeviri sürecinde de kaynak metin iletisinin, anlamının ve etkisinin erek metin ile hedef kitle üzerinde sağlanması durumu Lasswell'in iletişim süreci ile benzerlik göstermektedir. Bu yüzden, Genel İletişim Kuramı sorularını çeviri süreci sorularına şu şekilde dönüştürebiliriz:

\section{Kim çeviriyor? $\Longrightarrow$ Neyi? $\Longrightarrow$ Hangi kanalla? $\Longrightarrow$ Kim için? $\Longrightarrow$ Hangi etkiyle çeviriyor?}

Genel çeviri süreci bağlamında ele alınabilecek bu sorular, bize çeviri sürecinin işleyişini çevirmen üzerinden betimlemeye ve bu sürecin çözümlemesini yapmaya yönelik bir yaklaşım sunmaktadır. Lasswell'in iletişim modelindeki göndericiye yönelik olan "kim?” sorusunu biz çeviri süreci için "kim çeviriyor?” şeklinde sorabiliriz. Bu soru, "çevirmen” (çeviri eylemini gerçekleştiren kişi) olarak cevaplanabilir. Çeviriyi yapan kişinin çevirmen olduğu bilinen bir gerçektir fakat bu cevaptan asıl anlaşılması gereken şey tıpkı iletişim süreci modelinde olduğu gibi çeviri sürecinde de niteliksel olarak kimin çevirdiği ya da eylemi kimin gerçekleştirdiğidir. Kimin çevirdiği sorusunun cevabı bizi çevirmenin kimliği, dünya görüşü, ilgi alanı, eğitimi, ideolojisi, bilgi birikimi veya entelektüel birikimi gibi genel olarak bilişsel birikim olarak adlandırılan niteliksel duruma götürmektedir. Çevirmenin kimliğinin çözümlenmesi için sorulabilecek bu soru aynı zamanda çevirmenin özellikleri ile ilgili bir çeşit betimleme yapmak için de sorulabilir. İlk sorunun bizi çeviri eylemini gerçekleştiren özneye götürmesi iletişim sürecinde olduğu gibi çeviri sürecinin de çeviren özne üzerinden ilerleyerek betimlenebileceğinin bir göstergesidir. Genel İletişim Kuramı'ndaki diğer bir soru olan "neyi?” sorusu, çeviri sürecinde "neyi çeviriyor?" ya da başka bir şekilde "çevirmen neyi çeviriyor?" sorusuna dönüştürülebilir. Bu sorunun cevabı, "kaynak metnin anlamını" şeklinde verilebilir ya da "kaynak metin” olarak cevaplanabilir. Bu cevaptan da anlaşılması gereken şey sadece kaynak metin ya da adının ne olduğu değildir. Çünkü sadece "kaynak metin" dendiğinde akla kaynak metnin içeriğinden çok ne olduğu gelmektedir. Kaynak metnin ne olduğu çevirmen ve çeviri süreci açısından elbette önemlidir. Fakat, kaynak metnin ne olduğu, onun daha çok hangi türde olduğu, kime ait olduğu, ne zaman yazıldığı ve hangi metin olduğu ile ilgilidir. Kaynak metin türü, yazınsal (roman, şiir, tiyatro vb.), teknik (mühendislik, tıp, hukuk vb.) gündelik (kullanma kılavuzu, ilaç prospektüsü, yemek tarifi vb.) veya akademik (makale, bildiri, tez vb.) olabilir. Kaynak metnin türünü bilmek çevirmene

\footnotetext{
\begin{tabular}{r|l} 
Adres & Address \\
RumeliDE Dil ve Edebiyat Araşttrmaları Dergisi & RumeliDE Journal of Language and Literature Studies
\end{tabular} Osmanağa Mahallesi, Mürver Çiçeği Sokak, No:14/8 Osmanağa Mahallesi, Mürver Çiçeği Sokak, No:14/8 Kadıköy - İSTANBUL / TÜRKIYE 34714 Kadıköy - ISTANBUL / TURKEY 34714 e-posta: editor@rumelide.com e-mail: editor@rumelide.com, tel: +90 505 7958124, +90 2167730616 phone: +90 505 7958124, +90 2167730616
} 
dillerarası çeviri sürecinde nasıl bir yol izleyeceği ve çevirisini ne gibi yöntemlerle gerçekleştireceği konularında kolaylık sağlamaktadır. Çünkü farklı metin türleri için farklı çeviri yaklaşımları sergilemek gerekebilmektedir. Öte yandan kaynak metnin anlamı dendiğinde bu cevaptan anlaşılması gereken de kaynak metnin ne söylediğidir. Daha derin bir bağlamda düşünülecek olursa sorunun cevabı "kaynak metnin anlamı" şeklinde de verilmelidir. Kaynak metni başka bir dile ve kültüre aktaran çevirmen aslında kaynak metin üzerinden yazarının ve doğal olarak metnin anlatmak veya söylemek istediği şeyi, içeriğini, mesajını yani anlamını çevirmektedir. Başka bir deyişle, kaynak metni çevirmek onu bir nesne olarak değil de içerik olarak çevirmek gibi anlaşılmalıdır. Çünkü kaynak metin, yazarının hedef kitleye ulaştırmak istediği mesajın, anlamın ve söylenmek istenenin biçim bulmuş halidir. Bu cevap ile vurgulamak istediğimiz şey metnin içeriğidir. İşte çevirmen de bu içeriği ve anlamı aktarır. Görüldüğü gibi, "neyi çeviriyor?” sorusu, bizi çeviri sürecine dair kaynak metnin ne olduğu ve ne anlatmak istediği ile ilgili bilgilere ulaştırmaktadır.

Lasswell'in bir diğer sorusu olan "hangi kanaldan?" sorusu ise çeviri için "hangi kanalla çeviriyor?" şeklinde sorulabilir. Burada söylenmek istenen, çevirmenin kaynak metnin anlamını erek kitleye hangi kanal ile aktardığıdır. Çevirmenin hangi kanaldan bu aktarımı yaptığı sorusu, "erek metin" olarak cevaplanabilir. Çünkü çevirmen, bu süreçte çevirisini yaparken bir yandan da erek metni oluşturmaktadır. Erek metin ise, kaynak metnin bir yansımasıdır. Bu durumda, kaynak metin ile aynı türde olmalı ve onunla aynı içeriğe (anlam, mesaj) sahip olmalıdır. Böylece erek metin, orijinal mesajı, anlamı ve içeriği erek kitleye iletmede çevirmen dışında ikincil bir kanal (ya da araç) görevi görmektedir. Bir nesne olarak değerlendirildiğinde nesne-kanal olarak adlandırılabilecek erek metin olmazsa kaynak metindeki mesaj ve anlam da erek kitleye ulaşamaz. Böyle bir durumda da süreç tamamlanmamış olur. İletişim modelindeki "kime?” sorusu ise (dillerarası) çeviri süreci açısından "kim için çeviriyor?” (kime çeviriyor?) şeklinde sorulabilir. Bu sorunun cevabı "erek kitle için” (erek kitleye) şeklinde verilebilir. Bu cevap çevirinin yapıldığı dil, kültür, toplum ve coğrafyaya yöneliktir. Aynı zamanda da çevirmeni ve çeviri sürecinin işleyişini anlamak ya da hedef toplumu çözümlemek için bize çeşitli bilgiler sağlamaktadır. Çevirmen, bir orijinal metni başka bir dile aktarırken hedef toplumun sadece dilini değil kültürel değerlerini, ideolojisini, yaşam tarzını ve sosyo-ekonomik durumunu da bilmelidir. İster başka bir dil ve kültürden kendi dil ve kültürüne ister tam tersine bir aktarım yapıyor olsun her iki durumda da çevirmen kaynak ve hedef kültürü tanımalı ve çevirisini yaptığı metnin hangi kitleye hitap edeceğini göz önünde bulundurmalıdır. Çeviriyi duruma göre yönlendiren çevirmen, eğer varsa kaynak metindeki kaynak kültür ögelerini veya söylemlerini erek kültüre uygun bir şekilde aktarmalıdır. Böylece çeviri eylemi daha kontrollü ve sağllklı bir şekilde işleyiş göstermiş olur. Bu durumda, çevirinin kim için yapıldığı bilgisinin makro düzeyde erek kültür, toplum ve mikro düzeyde hedef kitle okuyucusu ile ilgili bilgi sağlayarak bir farkındalık sağladığını söyleyebiliriz.

Son olarak, iletişim sürecinin "hangi etkiyle?" sorusu çeviride "Hangi etkiyle çeviriyor?" olarak sorulabilir. Bu sorunun cevabı, "kaynak metnin etkisiyle" şeklinde verilebilir. Kaynak metnin içerik olarak bir anlamının, mesajının ve söylemek istediğinin bulunmasının yanı sıra kendi kültürü üzerinde bir de etkisi bulunmaktadır. Etki, kaynak metnin, okuyucu kitle üzerinde oluşturmayı hedeflediği bir durumdur. Metin türüne göre amacı değişebilen bu etki, yazınsal metinlerde okuyucuyu duygusal olarak etkilemek veya metnin okuyucuyu etki altına alarak onda duygusal açıdan değişiklikler yaratmak şeklinde olabilir. Teknik ve alansal metinlerde ise, okuyucuyu ilgili alana yönlendirmek ya da ona herhangi bir nesnenin kullanımı ile ilgili bilgi vererek daha işlevsel bir şekilde uygulama yapmasını sağlamak olabilir. İşte bu gibi etkiler, çeviri metinlerde de sağlanmalıdır. Başka bir deyişle, türü ne olursa olsun kaynak metnin okuyucusu üzerinde bırakmayı amaçladığı etkiyi aynı şekilde erek

Adres Address

RumeliDE Dil ve Edebiyat Araşttrmalar Dergisi $\quad$ RumeliDE Journal of Language and Literature Studies Osmanağa Mahallesi, Mürver Çiçeği Sokak, No:14/8 Osmanağa Mahallesi, Mürver Çiçeği Sokak, No:14/8 Kadıköy - İSTANBUL / TÜRKIYE 34714 Kadıköy - ISTANBUL / TURKEY 34714 e-posta: editor@rumelide.com e-mail: editor@rumelide.com,

tel: +90 505 7958124, +90 2167730616 phone: +90 505 7958124, +90 2167730616 
Communication and translation: An approach to mass communication theories from the perspective of translation / S. Dindar (pp. 1012-1026)

metin ile erek kültür okuyucusu üzerinde de olabildiğince sağlayabilmek gerekmektedir. Çeviri eylemine başlamadan önce bir kaynak metin okuyucusu olarak kaynak metnin içeriğini ve etkisini alan çevirmen, bu etkiyle çevirisini yaparsa onu ileterek erek kültürde de sağlayabilir. Böylece, erek kültür okuyucusu (hedef kitle) kaynak metnin etkisini, kaynak metin okuyucusu ile aynı şekilde hissedebilir. Etki, okuyucunun alımlamasına göre değişkenlik gösterebilen bir durumdur. Çünkü özellikle de yazınsal metin türlerinde her okuyucu aynı şeyden aynı oranda ve aynı şekilde etkilenmeyebilir. Fakat metnin yine de içeriğine bağlı olarak genel bir etki durumu vardır. Bu noktada çevirmenin amacı, kaynak metnin anlamı ve içeriği bağlamında yaratmak istediği genel etkiyi erek kültürde sağlayabilmektir.

Genel olarak bakıldığında, Lasswell’in iletişim modelinde amacın, iletişim sürecine gönderici açısından yaklaşarak sürece dair bir betimleme yapmak olduğunu söyleyebiliriz. Çeviri açısından bakıldığında da bu model, çeviri sürecine çevirmen üzerinden sorularla betimleyici bir yaklaşım sağlamıştır. Her iki durumda da iletişimi başlatan özneler ön plana çlkmaktadır ve süreç onlar üzerinden işleyiş göstermektedir. Böylece hem iletişim hem de çeviri sürecinin soru-cevap şeklinde açılayıcı bir betimlemesi yapılmıştır. Çeviri süreci ve Lasswell’in İletişim Modeli süreçlerinin bu şekilde benzerlik göstermesi aralarındaki ilişkiyi bir kez daha vurgulamakta ve bir iletişimsel çeviri sürecine işaret etmektedir.

\section{Sonuç}

Babil Kulesi efsanesinden hareketle, çeviri eyleminin ortaya çıkış amacının bile farklı dilleri konuşan insanlar arasında iletişim kurma ihtiyacını karşılamak olduğunu göz önüne aldığımızda çevirinin temelde bir iletişim şekli ve aracı olduğunu açık ve net bir şekilde söyleyebiliriz. Öte yandan, iletişim ve çeviri ilişkisi bağlamında çevirinin iletişimsel bir yanı olduğu düşüncesi kuramsal söylemlerle de doğrulanmış bir bilgidir. Çalışmamızda bu konuyla ilgili vermiş olduğumuz bazı önemli çeviribilim kuramcılarının söylemleri ışığında da dillerarası çevirinin farklı diller ve kültürler arasında iletişim sağlayan bir araç olduğunun altını çizebiliriz. İletişimde amaç, belirli bir kaynaktan çıkan mesajı bir kanal aracılığı ile düzgün bir şekilde alıcıya ulaştırmaktır. Böylece, gönderici ve alıcı arasında bir bilgi alışverişi ve aktarımı gerçekleşir. Aynı şekilde dillerarası çeviride de amaç belirli bir dilde ve kültürde yazılmış bir kaynak metnin anlamını, mesajını, söylemek istediğini başka bir dile ve kültüre aktarmaktır. Çeviride tıpkı iletişimde olduğu gibi bir kültürden diğerine aktarım sağlanmış olur. Söz konusu aktarım farklı dil ve kültürlerin birbirlerine çevrilmesiyle karşılıklı bir bilgi akışına veya alışverişine, etkileşime ve iletişim ağına dönüşmektedir. Böylece çevirinin süreç ve işleyiş olarak iletişime oldukça benzediğini ve çevirinin farklı toplumlar arasında ilişki, iletişim kuran ve köprü oluşturan bir kitle iletişim aracı olma özelliği gösterdiğini söyleyebiliriz.

Çalışmamızda, iletişim ve çeviri arasındaki ilişkiyi iletişim kuramı-çeviri bağlamında açıklamaya çalıştık. Bunun için de seçtiğimiz iki temel kitle iletişim kuramına çeviri açısından yaklaşarak onları çeviri sürecine uyarladık. Seçtiğimiz ilk kuram olan Shannon-Weaver İletişim Kuramı'nda, Shannon ve Weaver tarafından iletişim sürecini betimleyen bir model oluşturulmuştur. Kuramcılar bu modelde sırasıyla, bilgi kaynağı, gönderici, gönderilen sinyal, kanal, alınan sinyal, alıcı ve hedef şeklinde bir sınıflandırma ve aşamalandırma yaparak iletişim sürecini betimleyip kuramsal olarak açıklamışlardır. Ayrıca gürültü kaynağına da değinen kuramcılar, bu özellik ile iletişim alanında kendi dönemleri için yenilikçi bir yaklaşım benimsemişlerdir. Biz de bu modele çeviri açısından yaklaşarak onu çeviri sürecine uyarlayıp eşdeğer olacak şekilde sırasıyla, kaynak metin yazarı, kaynak metin, kaynak metnin anlamı, çevirmen, kaynak metnin anlamı, erek metin ve erek kitle olarak bir ilişkilendirme yaptık.

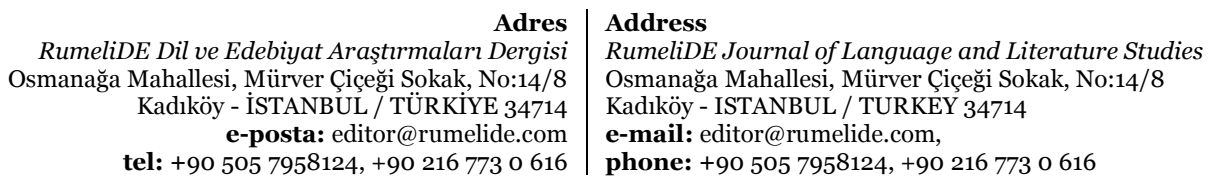


İletişim modelindeki gürültü kaynağını yazılı çeviri bağlamında devreye giremeyeceği için sürece dâhil etmedik. Bu yaklaşımla, bir iletişim aracı olarak çevirinin kuramdaki süreç ve işleyiş ile uygunluk gösterdiğini ve bu bağlamda bir iletişimsel çeviri süreci betimlemesi yapmış olduğumuzu söyleyebiliriz. Ayrıca, bir diğer önemli nokta da Shannon-Weaver İletişim Kuramına çeviri açısından yaklaştı̆̆ımızda çeviribilim kuramcılarının iletişimsel çeviri süreci ile ilgili daha önce değinmiş olduğumuz söylemlerinden izlere rastlamış olmamızdır. Özellikle de çeviri kuramcılarının değindikleri gönderici, mesaj, kanal, alıcı gibi aşamalar (Reiss, Berman, Nord), iletişim-çeviri ilişkilendirmesi yaptığımız yaklaşımımıza da yansımıştır. Böylece kuramcıların bu konu hakkındaki söylemleri de farklı bir yaklaşım ile irdelenmiştir.

Seçtiğimiz ikinci kuram, yine iletişim alanının temel kuramlarından olan Lasswell'in Genel İletişim Kuramı'dır. Genel İletişim Kuramı, iletişim sürecine göndericiyi merkeze alarak onun üzerinden sorduğu beş soruyla genel iletişim sürecini betimlemektedir. Lasswell, iletişim sürecini kim?, neyi?, hangi kanaldan?, kime?, hangi etkiyle söylüyor? şeklinde sorular sorarak gönderici özne açısından bu süreci aşamalandırmıştır. Genel İletişim Kuramı'ndaki bu sorulara cevap verilirken iletişim süreci sosyolojik bir açıdan da betimlenmektedir. İletişim sürecine dair bu sorular, süreçteki gönderici, mesaj içeriği, kanal, alııı ve etki ögelerine dair detaylı bir bilgi edinme firsatı sunmaktadır. Bu kuram için iletişimin amacı, gönderici mesaj içeriğinin etkisini koruyarak düzgün bir şekilde alıcıya ulaşmasıdır. Biz de iletişim süreci ile ilgili sorulara çeviri açısından yaklaşıp çeviri eylemini gerçekleştiren özne olan çevirmeni merkez alarak söz konusu soruları çeviri süreci sorularına dönüştürdük. Kim çeviriyor?, neyi çeviriyor?, hangi kanalla çeviriyor?, kim için çeviriyor? ve hangi etkiyle çeviriyor? şeklindeki sorular da iletişimde olduğu gibi çeviri sürecinde çevirmen, kaynak metnin anlamı, erek metin, erek kitle ve kaynak metnin etkisi ile ilgili detaylı bilgi edinmeyi ve bir betimleme yapmayı sağlamaktadır. $\mathrm{Bu}$ yapılırken de iletişimdeki gibi devreye sosyolojik durumların da girdiğini söyleyebiliriz. Lasswell’in Genel İletişim Kuramı'nı çeviriye uyarladığımızda da değinmiş olduğumuz çeviribilim söylemleri dolaylı olarak yine yaklaşımımıza yansımıştır. Lasswell sorularının çeviri açısından cevapları bizi mesaj aktarımı (Mänttäri), metin türü ve ikincil iletişim (Reiss, Berman), kültürel öğelerin aktarımı (Newmark, Nord, Levy) ve sosyo-kültürel unsurlar (Hatim\& Mason) hakkında bilgilere ulaştırmaktadır. Böylece konuyla ilgili çeviribilim kuramcılarının yapmış oldukları söylemleri de farklı bir açıdan desteklemiş olduğumuzu söyleyebiliriz.

$\mathrm{Bu}$ çalışmadaki yaklaşımdan hareketle, çeviri ve iletişim arasında kuramsal açıdan da bir örtüşüm yapılabileceğini belirtebiliriz. Bu örtüşüm daha çok yazılı ve dillerarası çeviri bağlamında gerçekleşiyor gibi görünse de diliçi (fr. traduction intralinguale / ing. intralingual translation) ve göstergelerarası çeviri (fr. traduction intersémiotique/ ing. intersemiotic translation) gibi çevirinin diğer türlerinde de gerçekleşmesi mümkündür. Başka bir deyişle, kurduğumuz kuramsal ilişki temel anlamda olup farklı kitle iletişim kuramlarına farklı çeviri türleri açısından yaklaşımları ya da kitle iletişim kuramlarını çeviri kuramları ile ilişkilendirmeyi mümkün kılabilmektedir. Bakış açılarını ve kuramları bu bağlamda çeşitlendirmek mümkündür. Böylece, kitle iletişim kuramlarının bir kitle iletişim aracı işlevi gören çeviriye uyarlanmalarının mümkün olduğunu ve bu yaklaşımın iletişim ve çeviribilim alanlarında farklı bakış açıları oluşturabileceğini belirtebiliriz. Çalışmamızda yapmış olduğumuz yaklaşım, iletişim ve çeviri ilişkisini kuramsal temelde örtüştürerek gösterip süreçleri bağlamında farklı açıdan bir analoji yapmamızı sağlamıştır. Bunun sonucunda da iletişimsel bir çeviri sürecinden bahsetmek mümkündür. Çevirinin bireyler, toplumlar ve kitleler arasında iletişim kurduğunu ve bir kitle iletişim aracı olduğunu göz önüne aldığımızda sadece uygulamaya dönük değil kuramsal açıdan da her çevirinin bir iletişimsel çeviri olma özelliği gösterdiğini söyleyebiliriz.

\footnotetext{
RumeliDE Dil ve Edebiyat Araștırmaları Dergisi Osmanağa Mahallesi, Mürver Çiçeği Sokak, No:14/8 Kadıköy - İSTANBUL / TÜRKIYE 34714 e-posta: editor@rumelide.com tel: +90 505 7958124, +90 2167730616 
Communication and translation: An approach to mass communication theories from the perspective of translation / S. Dindar (pp. 1012-1026)

\section{Kaynakça}

Berman, A. (1999). La traduction et la lettre ou l'auberge du lointain. Paris: Seuil.

Bulduklu, Y. \& Karaçor, S. (2019). Kitle İletişim Kuramları. Konya: Çizgi Kitabevi.

Guidère, M. (2010). Introduction à la traductologie. Bruxelles: De Boeck.

Hatim, B. \& Mason, I. (1990). Discourse and the Translator. London: Longman.

Jakobson, R. (1963). Essais de linguistique générale. Paris: Les Éditions de Minuit.

Munday, J. (2016). Introducing Translation Studies Theories and Applications. London: Routledge.

Rakovà, Z. (2016). Çeviri Kuramları. Yusuf Polat (Çev.). Ankara: Çevirmenin Yayını.

Reiss, K. (2000). Type, Kind and Individuality of Text, Decision making in translation. Susan Kitron (Tr.), L. Venuti (Ed.), The Translation Studies Reader, London: Routledge, 160-171.

Tahir Gürçağlar, Ş. (2011). Çevirinin ABC’si. İstanbul: Say.

Yalçın, P. (2015). Çeviri Stratejileri. Ankara: Grafiker.

Yaylagül, L. (2006). Kitle İletişim Kuramları, Egemen ve Eleştirel Yaklaşımlar. Ankara: Dipnot.

Yazıcı, M. (2005). Çeviribilimin Temel Kavram ve Kuramları. İstanbul: Multilingual. 